\title{
SISTEM INVENTORI BARANG DENGAN TEKNOLOGI AJAX
}

\author{
Anna Fitriya \\ Fakultas Teknik, Program Studi Teknik Informatika \\ Universitas Muria Kudus \\ Email: annafitriya@yahoo.com \\ Mukhamad Nurkamid \\ Fakultas Teknik, Program Studi Teknik Informatika \\ Universitas Muria Kudus \\ Email: nurkamid@gmail.com \\ Tutik Khotimah \\ Fakultas Teknik, Program Studi Teknik Informatika \\ Universitas Muria Kudus \\ Email: tutik.khotimah@gmail.com
}

\begin{abstract}
ABSTRAK
Sistem inventori barang pada pertokoan telah banyak dikembangkan untuk meningkatkan efektivitas dan efisiensi. Pada Toko Karya Indah, kegiatan yang berkaitan dengan inventori barang masih dilakukan secara manual sehingga pihak toko kesulitan untuk mengetahui data barang yang masih tersedia, habis, atau hampir habis. Selain itu, proses yang dilakukan membutuhkan waktu yang relatif lama. Oleh karena itu, diperlukan sistem inventori barang. Sistem dibangun dengan bahasa pemrograman PHP dan database MySQL. Sistem disertai teknologi AJAX (Asynchronous JavaScript And XML), khususnya AJAX autocomplete dan $A J A X$ validasi. Hasil yang diperoleh adalah pengolahan data pada sistem inventori barang dengan menggunakan $A J A X$ dapat dilakukan dengan lebih cepat dari pada tanpa $A J A X$.
\end{abstract}

Kata kunci: sistem inventori, $A J A X$.

\section{ABSTRACT}

Goods inventory system in the shops has been developed to improve the effectiveness and efficiency. In Karya Indah Store, activities that related to the inventory of goods are still done manually so that store difficult to know the data items are available, data item exhausted, or data item nearly exhausted. In addition, the process is done requires a relatively long time. Therefore, they necessary goods inventory system. This system is built by using PHP as the programming language and MySQL as database. This system is equipped with AJAX (Asynchronous JavaScript And XML) technology, especially autocomplete and validation. The result is a data processing in good inventory system by using AJAX can be done more quickly.

Keywords: inventory system, AJAX.

\section{PENDAHULUAN}

Sistem inventori barang [1][2][3][4][5] telah banyak dikembangkan untuk meningkatkan efektivitas dan efisiensi. Inventori atau persediaan adalah sejumlah bahan/barang yang disediakan oleh perusahaan, baik berupa barang jadi, bahan mentah, maupun barang dalam proses yang disediakan untuk menjaga kelancaran operasi perusahaan guna memenuhi permintaan konsumen setiap waktu [6]. Dari pengertian tersebut maka perusahaan jasa tidak memiliki persediaan, perusahaan dagang hanya memiliki persediaan barang dagang, sedangkan perusahaan industri memiliki 3 jenis persediaan yaitu persediaan bahan baku, persediaan dalam proses, dan persediaan barang jadi. Sistem inventori/persediaan barang merupakan suatu sistem yang menjelaskan bagaimana transaksi penerimaan barang dan transaksi penggunaan barang yang berisi tentang status stok barang itu sendiri yang dapat membantu meningkatkan produktivitas perusahaan

Toko Karya Indah adalah salah satu toko yang belum menerapkan sistem inventori barang. Pada Toko Karya Indah, penjualan dan pembelian dilakukan dengan pencatatan di buku penjualan atau hanya berupa nota saja. Barang yang masuk dan barang yang keluar tidak didata secara terstruktur. Akibatnya pihak toko akan kesulitan untuk mengetahui barang apa saja yang masih tersedia, dan barang apa saja 
yang sudah habis atau hampir habis sehingga perlu melakukan penambahan stok barang. Untuk mengetahui informasi tersebut, pihak toko harus menghitung jumlah barang satu per satu sehingga membutuhkan waktu yang lama. Informasi yang sulit dan lama diperoleh ini akan berakibat pada proses pengambilan keputusan yang lama dan atau kurang tepat, terutama pengambilan keputusan untuk menambah atau tidak menambah stok baru. Barang yang kurang laku tidak perlu dilakukan penambahan stok, sedangkan barang yang laku harus dilakukan penambahan stok sebelum barang itu habis. Apabila pihak toko salah mengambil keputusan, maka toko akan mengalami kerugian.

Untuk mengatasi masalah tersebut, diperlukan sistem inventori barang pada Toko Karya Indah. Dengan sistem tersebut, transaksi penjualan dan pembelian dapat dikelola melalui sistem. Informasi yang diperlukan dapat lebih cepat dan mudah diperoleh sehingga keputusan dapat diambil lebih cepat dan tepat.

Asynchronous JavaScript And XML (AJAX) [7][8] adalah penggabungan dari JavaScript dan XML yang membuat aplikasi web lebih interaktif. Tujuannya adalah untuk memindahkan sebagian besar interaksi pada komputer web surfer, melakukan pertukaran data dengan server di belakang layar, sehingga halaman web tidak harus dibaca ulang secara keseluruhan setiap kali seorang pengguna melakukan perubahan. Sistem yang menggunakan teknologi $A J A X$ dapat jauh lebih cepat dibandingkan dengan web tradisional biasa.

Pada penelitian ini, sistem inventori dibangun dengan menerapkan teknologi AJAX. Dengan teknologi AJAX diharapkan informasi yang ditampilkan lebih optimal dan sistem yang dihasilkan lebih ringan dan mudah diakses. Ada pun teknologi AJAX yang digunakan adalah AJAX autocomplete dan $A J A X$ validasi. AJAX autocomplete terdapat dalam transaksi penjualan dan transaksi pembelian yang digunakan untuk memanggil data barang tanpa harus me-load seluruh halaman. Sedangkan AJAX validasi berfungsi untuk memberikan validasi yang lebih cepat pada form penginputan data dan penginputan transaksi untuk memastika bahwa data yang dimasukkan adalah data yang valid.

\section{METODE PENELITIAN}

Penelitian ini dilaksanakan dengan langkah-langkah penelitian sebagai berikut:

a. Pengumpulan data

Ada beberapa metode yang digunakan untuk melakukan pengumpulan data, antara lain:

1) Observasi

Observasi dilakukan dengan melakukan pengamatan pada objek studi, yaitu Toko Karya Indah yang terletak di Jalan AKBP R Agil Kusumadya No 89 Kudus. Ada pun kegiatan yang diamati adalah kegiatan pembelian barang melalui suplier, pencatatan barang yang masuk, pencatatan stok barang, transaksi penjualan kepada konsumen, dan pencatatan barang yang keluar.

2) Wawancara (Interview)

Metode ini dilakukan dengan melakukan tanya jawab secara langsung kepada pihakpihak yang terlibat, seperti pemilik toko dan petugas penjaga toko.

3) Dokumentasi

Metode ini dilakukan dengan mengumpulkan dokumen-dokumen yang berkaitan dengan inventori barang, seperti struk pembelian dan penjualan, kartu stok barang.

4) Literatur

Metode ini dilakukan untuk mengumpulkan materi-materi yang berkaitan dengan sistem inventori.

b. Analisis

Pada tahap analisis, ada beberapa kegiatan yang dilakukan. Pertama adalah melakukan analisis terhadap objek studi, yaitu Toko Karya Indah. Kegiatan ini dilakukan untuk mengetahui bagaimana sistem inventori yang sedang berjalan di Toko Karya Indah dan masalah apa saja yang terjadi. Setelah merumuskan masalah yang ada, langkah selanjutnya adalah mencari solusi. Setelah menentukan solusi yang dipilih, langkah berikutnya adalah melakukan analisis kebutuhan, baik kebutuhan data dan informasi, mau pun kebutuhan infrastruktur yang diperlukan untuk sistem inventori.

c. Perancangan

Pada tahap perancangan, ada beberapa hal yang dilakukan, yaitu perancangan sistem, perancangan database, dan perancangan interface. Perancangan sistem dilakukan untuk menggambarkan alur proses dari sistem inventori yang baru. Perancangan sistem dilakukan dengan menggunakan Data Flow Diagram (DFD) [9]. Sedangkan perancangan database 
dilakukan untuk menghasilkan tempat penyimpanan data yang sesuai dengan kebutuhan. Perancangan database diawali dengan membuat Entity Relationship Diagram (ERD)[10] kemudian melakukan transformasi ke tabel. Setelah proses transformasi dari ERD ke tabel, proses selanjutnya adalah melakukan normalisasi [10] terhadap tabel-tabel yang berasal dari relasi. Proses ini dilakukan untuk menghasilkan tabel-tabel yang normal. Pada perancangan interface, yang dilakukan adalah menyusun tampilan form untuk proses penginputan data, seperti: form input data master barang, form transaksi penjualan dan pembelian. Selain itu juga merancang tampilan dari informasi yang ingin dihasilkan dari sistem, seperti informasi stok barang.

d. Implementasi

Tahap implementasi adalah tahap pengkodean terhadap rancangan-rancangan yang telah didefinisikan sehingga akan membentuk sistem inventori sesuai dengan yang diharapkan. Pengkodean sistem dilakukan dengan menggunakan bahasa pemprograman PHP. Rancangan database juga diubah menjadi sebuah basis data yang dapat digunakan untuk menyimpan data sesuai kebutuhan. Pada sistem ini, basis data dibuat dengan MySQL.

e. Pegujian

Setelah diperoleh aplikasi sistem inventori, tahap selanjutnya adalah ke pengujian untuk menguji fitur-fitur pada sistem dengan menggunakan pengujian blackbox.

Ada pun kerangka pemikiran dari penelitian ini dapat dilihat pada gambar 1.

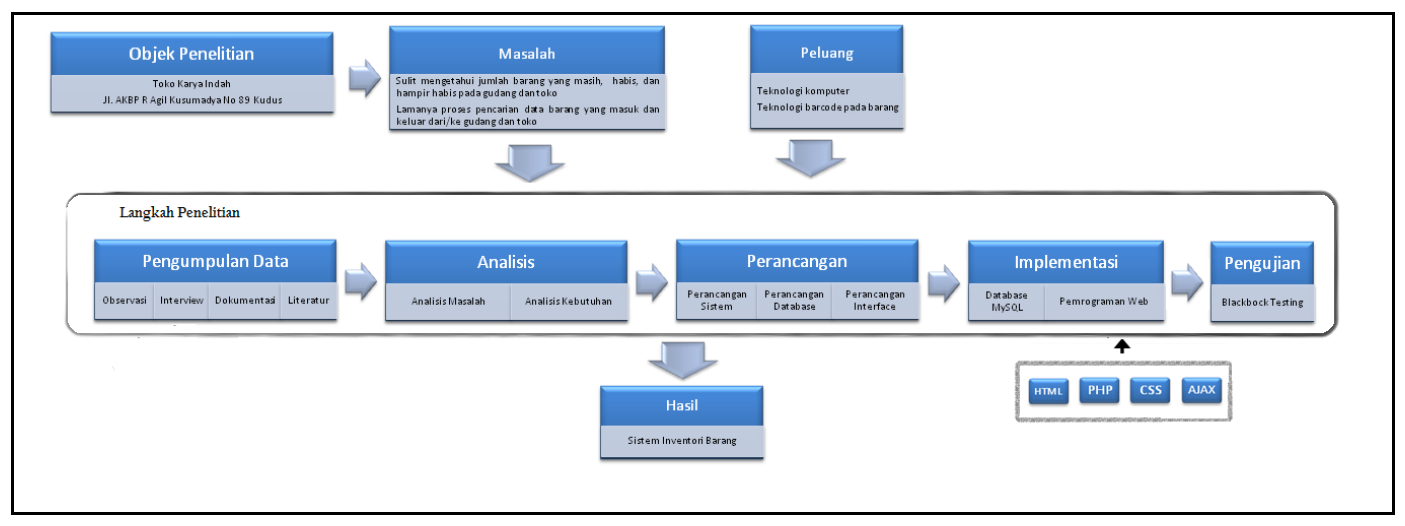

Gambar 1. Kerangka Pemikiran

\section{HASIL DAN PEMBAHASAN}

\subsection{Gambaran Sistem Inventori Barang dengan Teknologi AJAX}

Pada penelitian sistem inventori barang ini tidak hanya menggunakan web model biasa (tradisional), tetapi web yang disertai dengan teknologi Asynchronous JavaScript And XML (AJAX)[7]. Pada web tradisional, browser membuat sebuah HTTP request yang dikirim ke server, misalnya index.html. Pada model ini, server mengirimkan response berisi seluruh halaman termasuk header, logo, navigasi, footer, dll. Ketika mengeklik next maka akan menampilkan halaman baru (artinya, header, logo, footer, navigasi dikirim ulang) dan seterusnya akan mengirimkan data halaman baru setiap diminta request dari user. Halaman seperti ini tidak menjadi masalah ketika data yang ditampilkan tidak memerlukan response yang cepat. Namun, akan menjadi masalah jika user menginginkan response yang cepat, misalnya ketika dipilih drop-down tertentu maka dapat ditampilkan berubah menurut nilai dari drop-down. Arsitektur model tradisional dapat dilihat pada gambar 2.

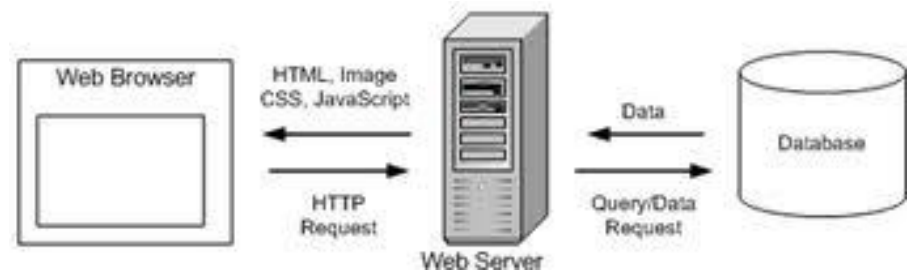

Gambar 2. Arsitektur Web Tradisional [7] 
Web yang disertai model $A J A X$ akan berkomunikasi dengan server tanpa harus me-refresh semua halaman. Konsep ini berbeda dengan aplikasi web sistem tradisional. Dalam model AJAX, aksi dari sisi klien dibagi menjadi dua bagian, yaitu layer user interface dan layer AJAX. Arsitektur model AJAX dapat dilihat pada gambar 3 .

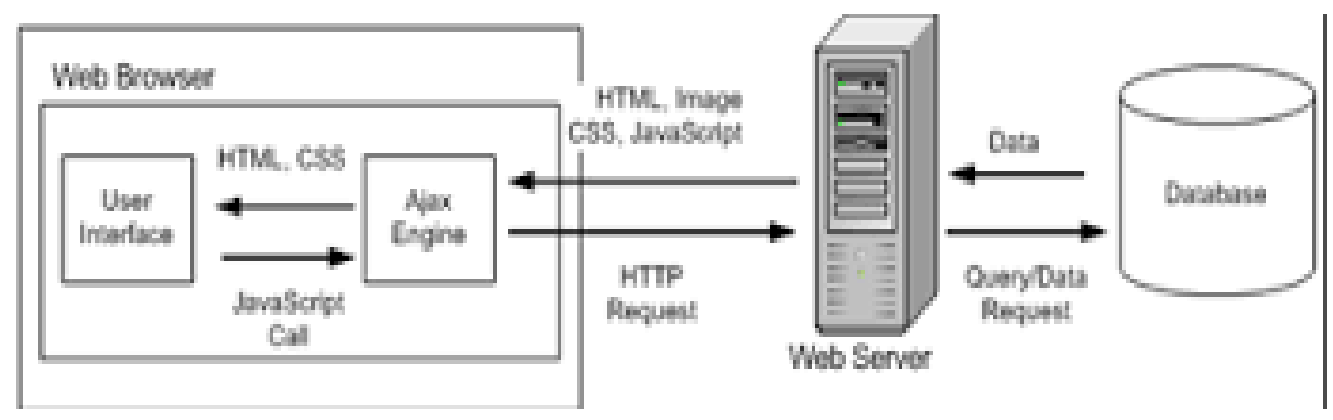

Gambar 3. Arsitektur Model AJAX [7]

Ketika user mengeklik sebuah link atau mengirimkan sebuah form maka input tersebut akan ditangani oleh layer AJAX dan diinteraksikan dengan server, kemudian meng-update user interface (UI). Jadi, dalam AJAX, internal si UI secara logika terpisah dengan interaksi jaringan.

Pendekatan yang digunakan $A J A X$ adalah bagaimana mengirimkan jumlah data yang kecil dari dan ke server atas request dari user. Model aplikasi web tradisional dimana browser akan me-respons sendiri atas inisialisasi request, memproses request dari web server. Dalam AJAX terdapat layer yang diberi nama AJAX engine untuk menangani komunikasi. AJAX Engine adalah sebuah obyek JavaScript atau function yang dipanggil ketika informasi diperlukan dari server.

Proses yang dilakukan mesin AJAX (AJAX Engine) adalah menerima respons dari server, melakukan parsing data dan melakukan sedikit perubahan untuk keperluan menampilkan informasi. Oleh karena proses mengirimkan sedikit informasi, jika dibanding dengan model aplikasi web tradisional, maka user interface di-update lebih cepat dan user mampu melakukan pekerjaannya dengan cepat [7][8].

Data Flow Diagram [9] adalah suatu diagram yang menggambarkan suatu arus data pada sistem. Gambar 5 adalah Data Flow Diagram pada sistem inventori barang. Dalam sistem inventori, terdapat lima entitas eksternal, yaitu kepala, gudang, kasir, supplier, dan pelanggan.

Ada pun tabel yang dihasilkan antara lain : tabel user, tabel kategori, tabel barang, tabel supplier, tabel pembelian, tabel penjualan, tabel pelanggan, tabel kerusakan, tabel pembelian_detail, dan tabel penjualan_detail. Sedangkan relasi dari masing-masing tabel dapat dilihat pada gambar 4 .

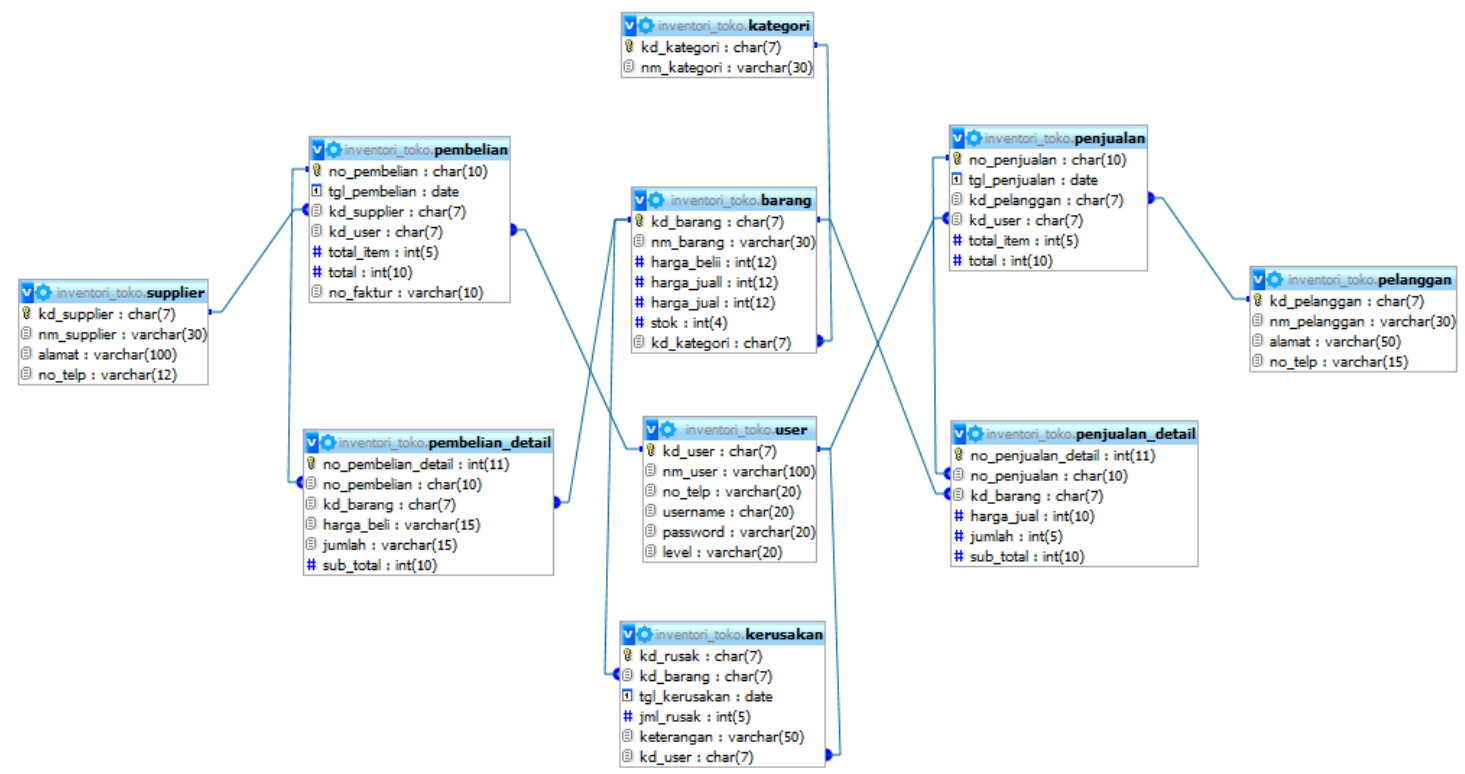

Gambar 4. Relasi Tabel Sistem Inventori Barang 


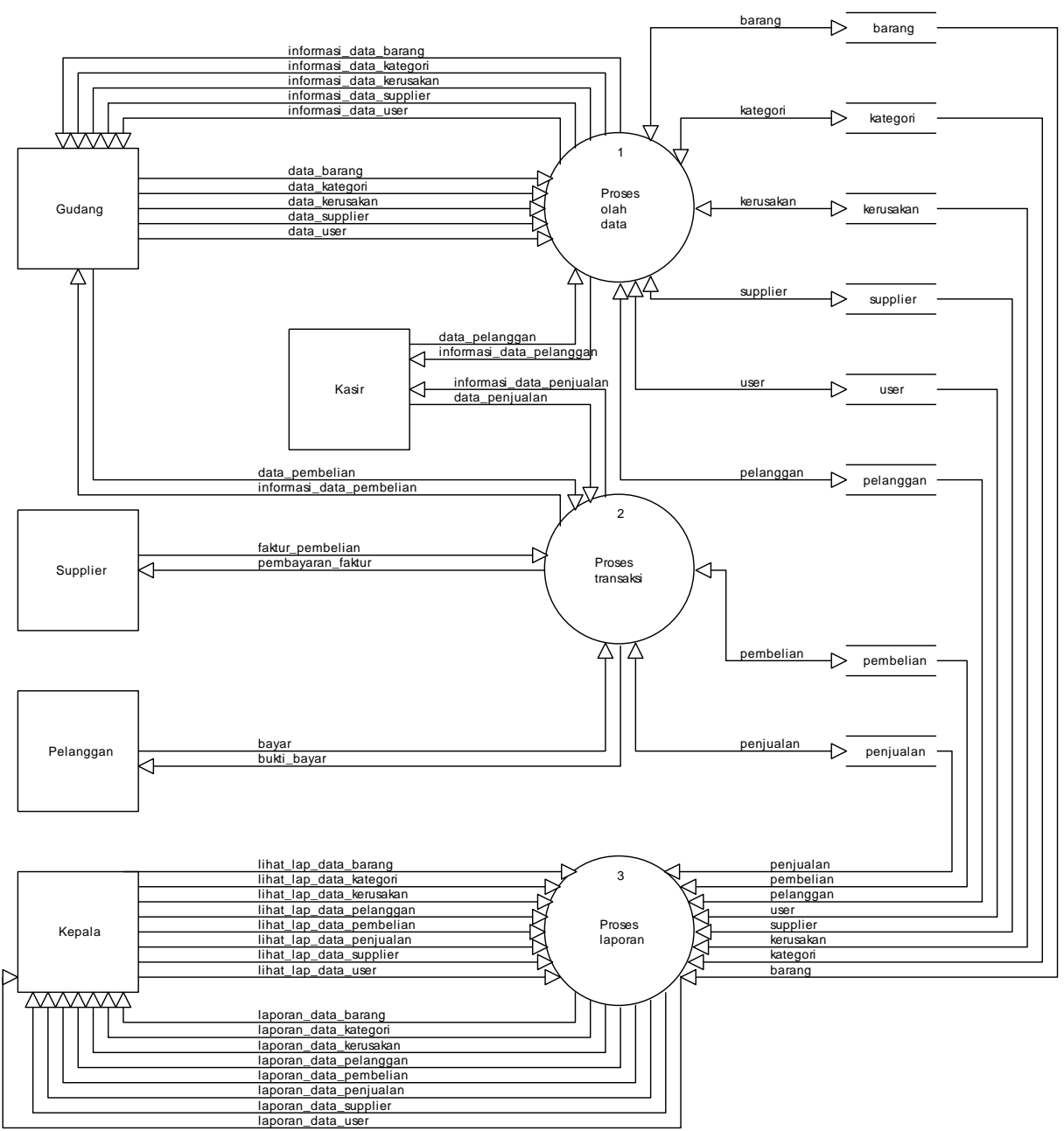

Gambar 5. DFD Sistem Inventori Barang

\subsection{Implementasi Sistem Dengan AJAX}

Dalam sistem inventori ini, ada 3 level hak akses, yaitu kepala, gudang, dan kasir. Level gudang bertugas menginputkan data barang yang masuk melalui transaksi pembelian, sedangkan level kasir bertugas menginputkan data barang yang keluar melalui transaksi penjualan. Level kepala hanya melihat informasi barang yang masuk dan informasi barang yang keluar.

Setelah user sukses melakukan peng-input-an di halaman login menggunakan hak akses gudang, maka halaman menu sistem dengan hak akses gudang akan menampilkan data stok barang yang hampir habis dengan jumlah minimal barang yang sudah ditentukan seperti pada gambar 6 .

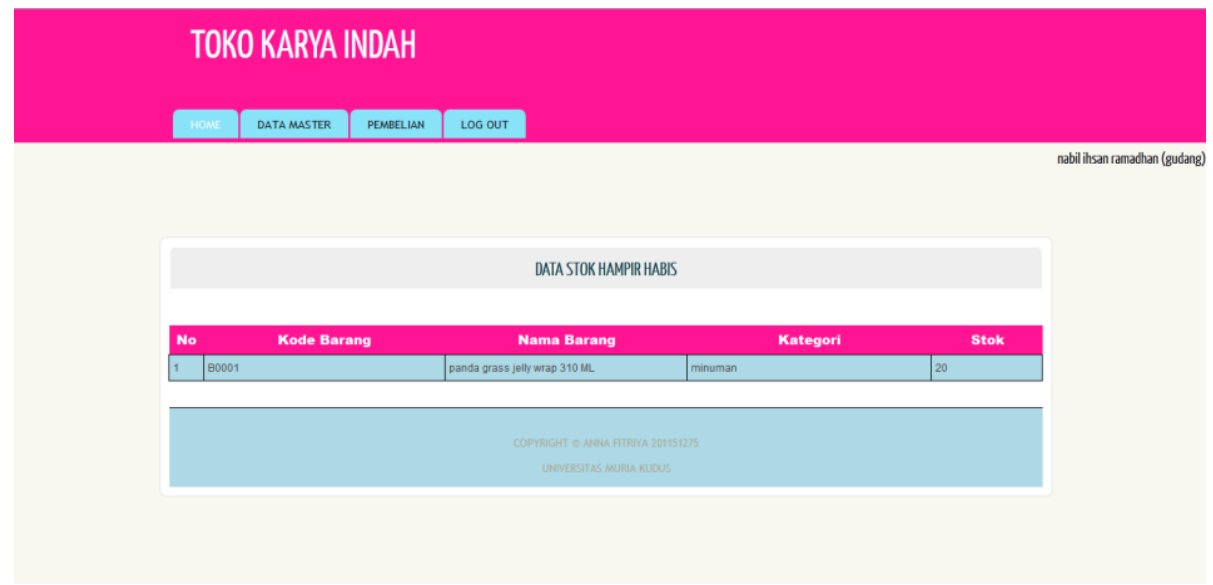

Gambar 6. Halaman Utama Hak Akses Gudang 
Jika user gudang ingin menambah data barang, maka user gudang akan menuju halaman tambah data barang yang dapat dilihat pada gambar 7 .

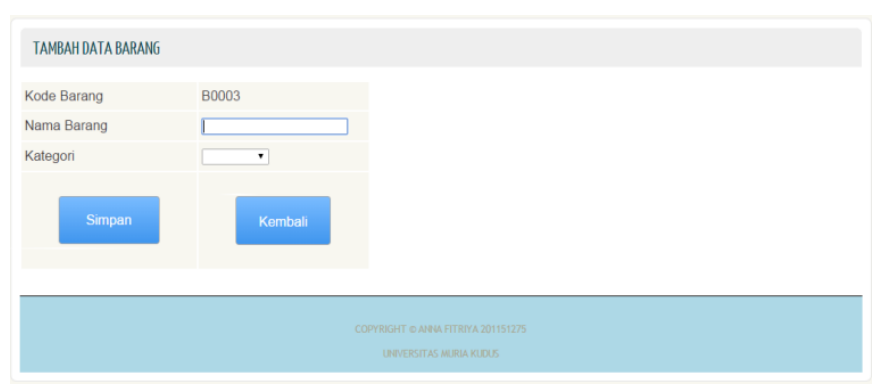

\section{Gambar 7. Halaman Input Data Barang}

Pada halaman tambah data barang terdapat tiga field yaitu kode barang, nama barang, dan nama kategori. User gudang hanya mengisi nama barang, dan nama kategori karena bagian kode barang sudah otomatis bertambah satu waktu awal membuka halaman data barang. Jika nama barang tidak di-input , maka akan muncul pesan validasi seperti pada gambar 8 .

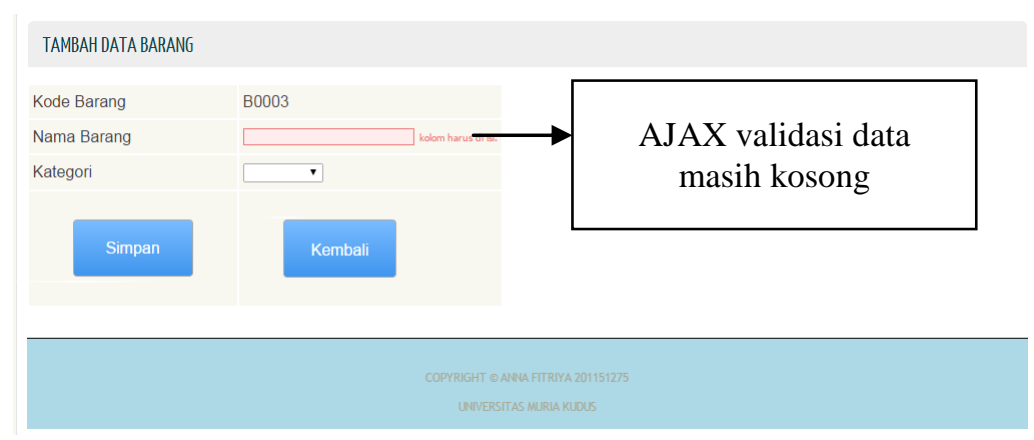

Gambar 8. Validasi Input Data Barang Yang Kosong

Jika user gudang ingin menambah data supplier, maka user gudang akan menuju halaman tambah data supplier yang dapat dilihat pada gambar 9.

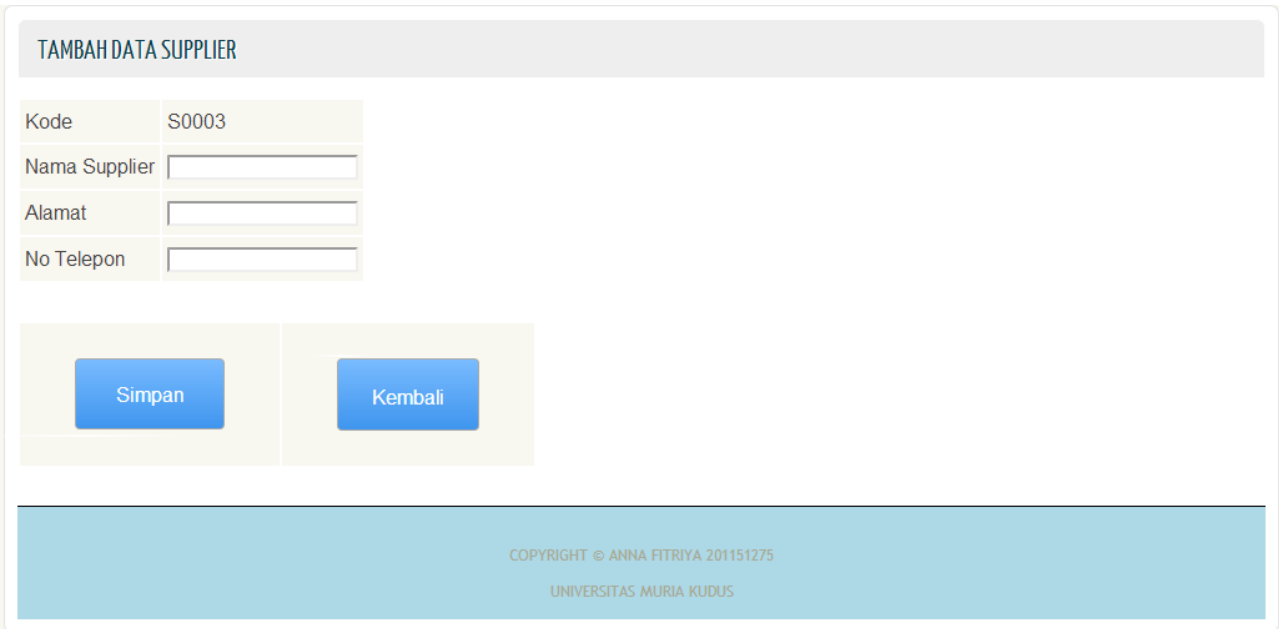

Gambar 9. Halaman Input Data Supplier

Pada halaman tambah data supplier terdapat empat field yaitu kode supplier, nama supplier, alamat supplier, dan nomor telepon supplier. User gudang hanya mengisi nama supplier, alamat supplier, dan nomor telepon supplier karena bagian kode supplier sudah otomatis bertambah satu waktu awal membuka halaman data supplier. Jika data supplier tidak di-input lengkap, maka akan muncul pesan validasi seperti pada gambar 10 . 


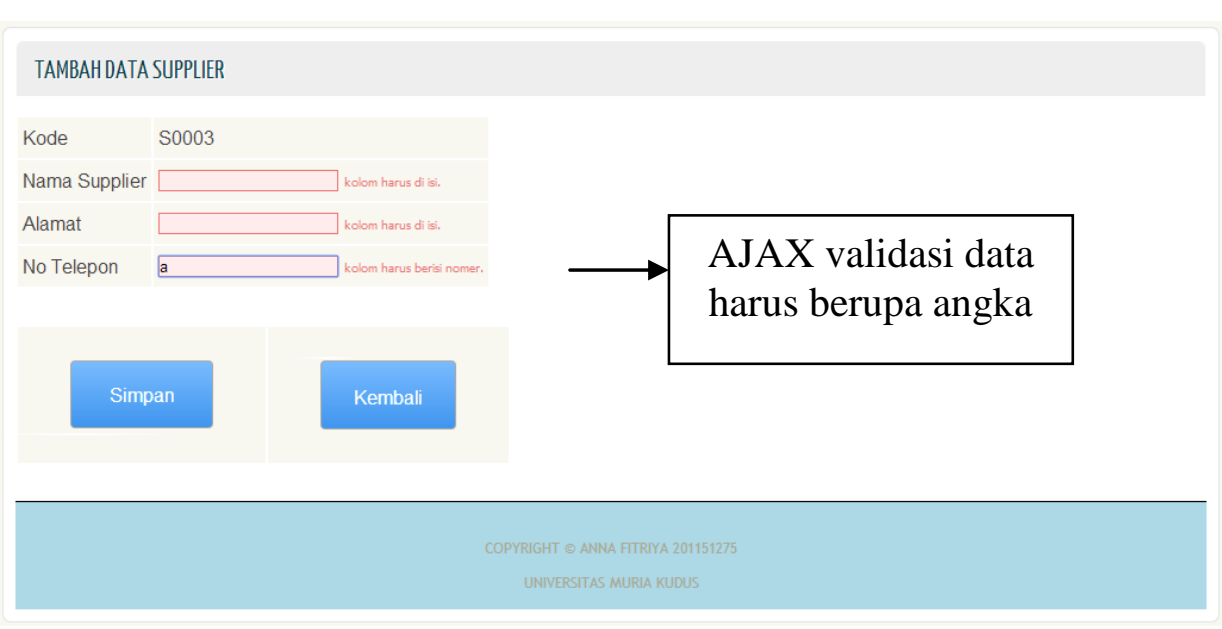

Gambar 10. Validasi Input Data Supplier

Pada form transaksi pembelian terdapat peng-input-an dua tabel, yang pertama peng-input-an pada tabel pembelian detail, dan kemudian peng-input-an pada tabel pembelian. Langkah pertama yang dilakukan user gudang adalah meng-input-kan kode barang dan otomatis akan muncul detail dari kode barang yang telah di-input-kan. Di dalam form transaksi pembelian, terdapat AJAX autocomplete yang berfungsi mempermudah user gudang dalam melakukan pencarian data barang secara otomatis dan cepat. Setelah melakukan peng-input-an kode barang, user gudang meng-input-kan jumlah barang yang masuk, kemudian klik button "Tambah" dan tersimpan di dalam tabel pembelian detail. Jika terjadi kesalahan peng-input-an, maka klik button "Remove" maka data yang tersimpan pada tabel pembelian detail akan terhapus. Jika tidak, maka dilanjutkan dengan proses peng-input-an nama supplier dan nomor faktur supplier kemudian klik button "Simpan" maka data akan tersimpan ke dalam tabel pembelian. Menu transaksi pembelian pada hak akses gudang dapat dilihat pada gambar 11.

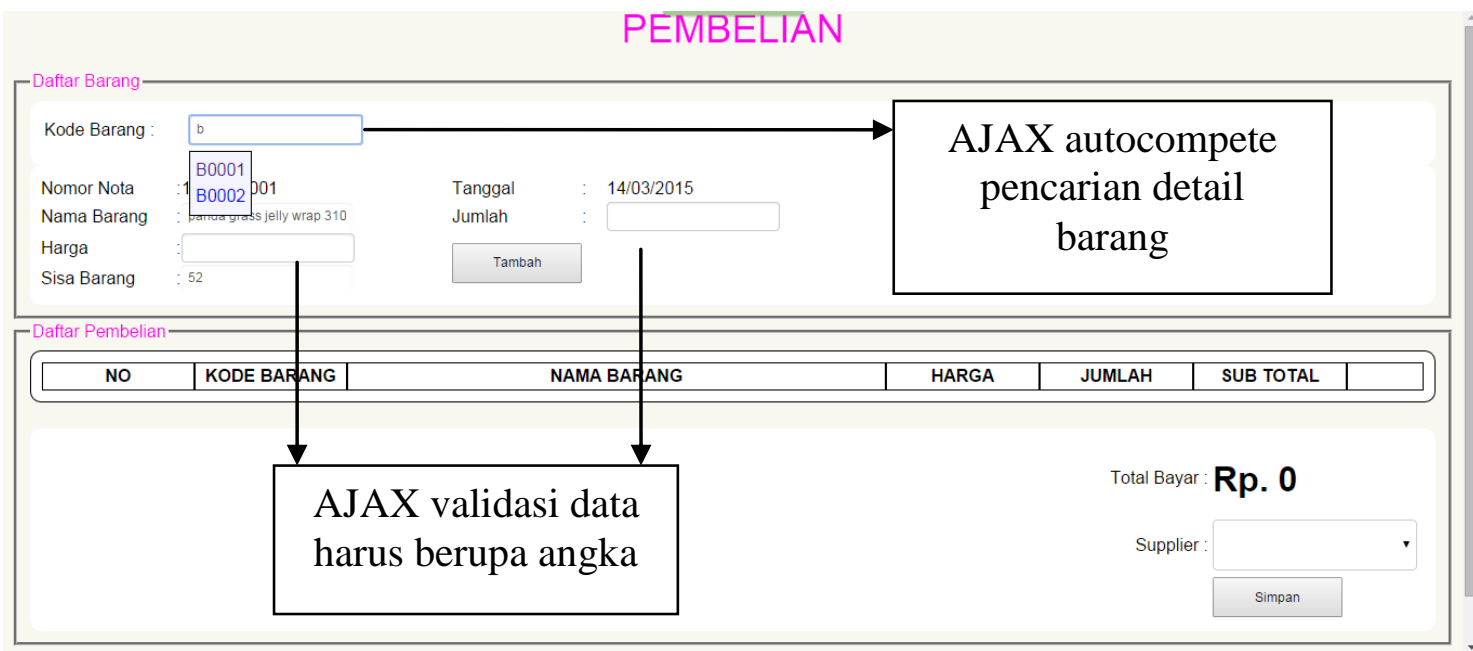

\section{Gambar 11. Form Transaksi Pembelian}

Pada form transaksi penjualan terdapat peng-input-an dua tabel, yang pertama peng-input-an pada tabel penjualan detail, dan kemudian peng-input-an pada tabel penjualan. Langkah pertama yang dilakukan user kasir adalah meng-input-kan kode barang dan otomatis akan muncul detail dari kode barang yang telah di-input-kan. Di dalam form transaksi penjualan, terdapat AJAX autocomplete yang berfungsi mempermudah user kasir dalam melakukan pencarian data barang secara otomatis dan cepat. Setelah melakukan peng-input-an kode barang, user kasir meng-input-kan jumlah barang yang keluar, kemudian klik button "Tambah" dan tersimpan di dalam tabel penjualan detail. Jika terjadi kesalahan peng-input-an, maka klik button "Remove" maka data yang tersimpan pada tabel penjualan detail akan terhapus. Jika tidak maka dilanjutkan dengan proses peng-input-an nama pelanggan kemudian klik button "Simpan" maka data akan tersimpan ke dalam tabel penjualan. Menu transaksi Penjualan pada user kasir dapat dilihat pada Gambar 12. 


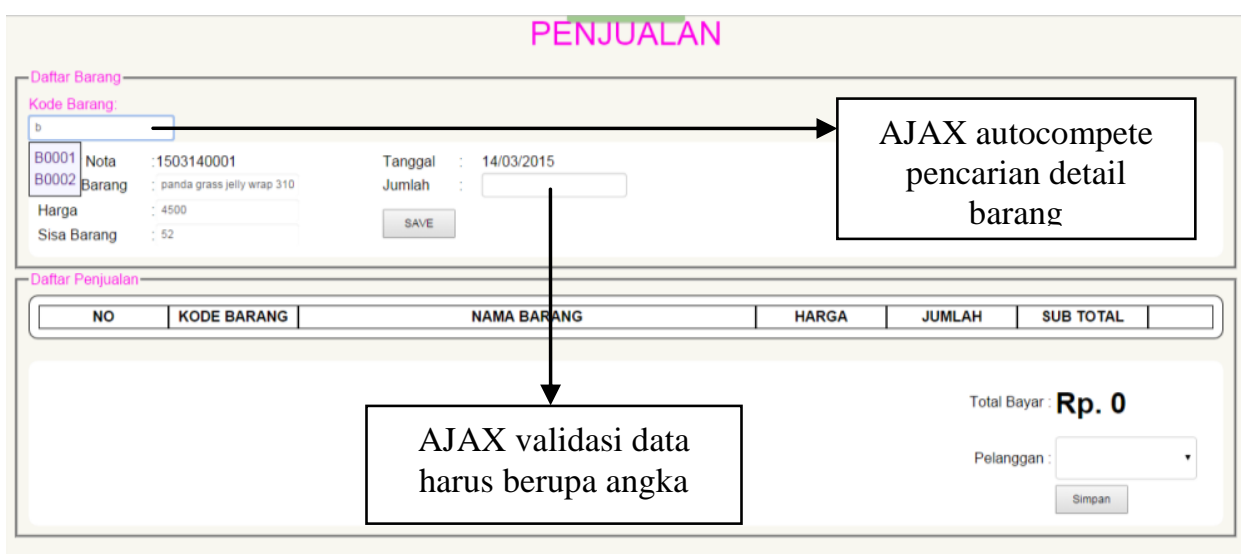

KEMBALI

Gambar 12. Form Transaksi Penjualan

\section{KESIMPULAN}

Dari hasil penelitian ini dapat disimpulkan sebagai berikut:

1) Sistem inventori barang dapat meningkatkan efektivitas dan efisiensi.

Dengan adanya sistem ini, pihak toko dapat memperoleh informasi tentang barang yang masih tersedia, barang yang habis atau barang yang hampir habis dengan mudah dan cepat. Dengan informasi yang mudah dan cepat ini, pihak toko dapat mengambil keputusan lebih awal untuk menambah stok baru bagi barang yang habis atau hampir habis melalui transaksi pembelian. Pihak toko juga dapat mengambil keputusan untuk tidak menambah stok baru untuk barang yang masih banyak.

2) Penggunaan teknologi $A J A X$ dapat membuat sistem lebih ringan diakses.

Teknolgi AJAX yang digunakan dalam sistem inventori toko adalah AJAX autocomplete dan AJAX validasi. AJAX autocomplete terdapat pada form transaksi penjualan dan transaksi pembelian, sedangkan $A J A X$ validasi terdapat pada semua form. AJAX autocomplete digunakan dalam pemanggilan data barang tanpa me-load seluruh halaman sehingga lebih ringan diakses. Sedangkan $A J A X$ validasi digunakan untuk memberikan validasi terhadap inputan untuk memastikan bahwa data yang dimasukkan adalah data yang valid.

\section{DAFTAR PUSTAKA}

[1] Krisnawan, W, 2008. "Sistem Informasi Persediaan Barang Mebel dengan Menggunakan Visual Basic.Net: Studi Kasus CV Cipta Nuansa Nusantara Jepara", Skripsi, Fakultas Teknologi Informasi Stikubank, Semarang

[2] Alfian, R. 2013. "Sistem Inventory Stock Barang: Studi Kasus CV Berkah Alam", Skripsi, Fakultas Teknologi Industri Universitas Pembangunan Nasional, Jawa Timur

[3] Prasetyo, Y. 2007. "Komputerisasi Sistem Persediaan Barang: Studi Kasus Grahadita Komputer Sukoharjo". Tugas Akhir, Fakultas Matematika dan Ilmu Alam Universitasn Sebelas Maret, Surakarta.

[4] Yuhendra, dan Poerwanta, Rendi, 2013, "Perancangan Sistem Inventory Spare Parts Mobil pada CV. Auto Parts Toyota Berbasis Aplikasi Java", Jurnal TEKNOIF, Vol 1, No.2, Edisi Oktober 2013

[5] Noviandi, BM, Destiani, Dini, dan Partono, 2012, "Perancangan Sistem Informasi Inventori Barang di Bank Sampah Garut", Jurnal Algoritma, Vol 9 No 32

[6] Margaretha, Farah, 2004, Teori dan Aplikasi Manajemen Keuanga: Investasi dan Sumber Dana Jangka Pendek, Jakarta, Grasindo

[7] Sunyoto, A. 2007. AJAX - Membangun Web dengan Teknologi ASYNCHRONOUSE JavaScript \& $X M L$, Andi Offset, Yogyakarta

[8] Dell' Aringa, T. 2006. Bring Your Website to Live with AJAX and DHTML. DMXzone.com, Netherlands

[9] Kendall, Kenneth E \& Julie E Kendall. 2011. Systems Analisys and Design Eight Edition. Prentice Hall

[10] Ramakrishnan, Raghu \& Johannes Gehrke. 2003. Database Management System Third Edition. Mc Graw Hill 